\title{
INFLUENCE OF PHOSPHORUS FERTILIZER ON YIELD AND OIL OF SAFFLOWER (CARTHAMUS TINCTORIUS) VARIETIES UNDER RAINFED CONDITION
}

\author{
SOFY, S. O. - HAMA, S. J. ${ }^{*}$ - HAMMA-UMIN, B. O. \\ Department of Biotechnology and Crop Science, College of Agricultural Engineering Sciences, \\ University of Sulaimani, Sulaymaniyah, Iraq \\ (e-mails:shno.sofy@univsul.edu.iq, bestoon.omar@univsul.edu.iq) \\ *Corresponding author \\ e-mail: shara.hama@univsul.edu.iq \\ (Received $30^{\text {th }}$ Oct 2019; accepted $12^{\text {th }}$ Feb 2020)
}

\begin{abstract}
This investigation was conducted during the winter seasons of 2017-2018 the Experimental Farm of the College of Agricultural Sciences, University of Sulaimani at Bakrajo, using split plot design to study the effect of three levels of phosphorus fertilizer on the growth, yield and yield components of safflower varieties. Three varieties namely Zaafarani, Aidn and; Al-shamia, were applied to the main plots, three phosphorus fertilizer levels $(0,50$ and $100 \mathrm{~kg}$ P2O5/ha from Tsp. 48\% source, were implemented in the subplots. Comparisons between means were carried out by the least significant difference (L.S.D) at $1 \%$ and $5 \%$ level of significance. The results showed that the Al-shaima varieties produced the best values at $15398.22 \mathrm{Kg} / \mathrm{h}$ and $1914.06 \mathrm{Kg} / \mathrm{h}$ followed by Aidn with values of $14508.77 \mathrm{Kg} / \mathrm{h}$ and 1655.72 for biological yield and seed yield respectively, finally the lowest values of $13662.88 \mathrm{Kg} / \mathrm{h}$ for biological yield and $1914.06 \mathrm{Kg} / \mathrm{h}$ for seed yield produced by Zaafarani. While the highest oil percentage was obtained from Zaafarani with values of $32.28 \%$ followed by Aiden with value of $29.62 \%$, finally the lowest value of $28.10 \%$ was obtained from variety Al-shamia. The application of $100 \mathrm{Kg} \mathrm{P} / \mathrm{ha}$ was found to be the best level for producing the highest seed yield with the highest percentage of oil. The trait of 100 seed weight showed a highly significant and positive correlation with seed yield, whereas the number of seeds/plant exerted the highest direct effect on seed yield $\mathrm{Kg} / \mathrm{ha}$, both traits were observed to be the most important trait for seed yield improvement in safflower.
\end{abstract}

Keywords: safflower production, fertilization, growth parameters, protein percentage, oil components, correlation and path coefficient analysis

\section{Introduction}

Safflower (Carthamus tinctorius L.) is an important annual industrial crop which is classified as a composite. It has more than 150 species that are scattered from Spain to North Africa, West Asia and India (Rastgou, 2013). These in turn are considered as the parental species of the cultivated species $(C$. tinctorius L.) in fact $(C$. persicus, and flavenscens) are the common subsidiary members of the Oak Forest association in Kurdistan (Guest, 1966). The stem, leaves, seeds and flowers are used as vegetable and industrial oil, bird feed, forage plant, medicinal purpose and for its colorful petals used as food coloring and flavoring agent (Dordas, and Sioulas, 2008). The oil content of seeds in Safflower is approximately 35 to 50 percent. Safflower oil preferred for its higher poly unsaturated fatty acid (78\% linoleic acid) which reduces blood cholesterol level (Belgin and et al., 2007) also contains tocopherols, known to have antioxidant effect and high vitamin E content. For this reason, safflower oil is used in the diets of patients with cardiovascular disease, and bears great importance for its anti-cholesterol effect (Arsalan and Tuntruk, 2003). Safflower has different varieties from local to wild ones which are adapted to distinct climates in Iraq. This plant is considered as an almost tolerable plant to 
different conditions, because it is adapted to different weather conditions (Omidi-Tabrizi et al., 2000). In Safflower, some physiological treats like growth, seed quality and oil content are controlled by variety, different for instance plant density, and chemical fertilizer application (Weiss, 2000). But, the productivity of safflower is very low as the crop is cultivated under nutrient stress environment conditions. This necessitates rational application of these elements as they have become limiting factor for obtaining higher yields in safflower. Phosphorus (P) is vital to plant growth and is found in every living plant cell. It is involved in several key plant functions, including energy transfer, photosynthesis, transformation of sugars and starches, nutrient movement within the plant and transfer of genetic characteristics from one generation to the next (Sultenfuss and Doyle, 1999). Phosphorus (P) is the most limiting nutrient for crop growth and yield in many regions of the world (Rodriguez and Goudriaan, 1999), and application of $\mathrm{P}$ fertilizer represents an important measure to correct nutrient deficiencies and to replace nutrients having been removed in the products harvested (Dambroth and El-Bassam, 1990). However, recovery of fertilizer $P$ in the first year is often below $15 \%$ and hardly reaches $50 \%$ after 30 years (Roy et al., 2000).

Therefore, the aim of this study was to evaluate the impact of phosphorous apply on growth, yield and oil percentage of safflower and to determine the best variety of safflower for yield and oil percentage.

\section{Materials and methods}

This study investigated in Sulaimani region, at Experimental Farm of the College of Agriculture Science Engineering, University of Sulaimani at Bakrajo located in the southwest of Sulaimani city (Latitude: $35^{\circ} 33^{\prime} \mathrm{N}$; Longitude $45^{\circ} 27^{\prime}$ Est altitude of approximately $830 \mathrm{~m}$ ) during the winter season of 2017-2018. The meteorological data of Bakrajo location is shown in Table 1. The experimental area plots were ploughed twice, harrowed and well leveled. A brief account of some physical and chemical properties of the experimental soil is given in Table 2.

Three safflower varieties were selected for cultivation, which has been provided by The Sulaimani Agricultural Research Center, namely; Zaafarani, Aidn and; Al-shamia. The experiment was arranged as split- plot layout. The varieties were implemented in the main plots and conducted with Randomized Complete Block Design (RCBD), different levels of Phosphorus fertilizer (0, 50 and $100 \mathrm{Kg} \mathrm{P}_{2} \mathrm{O}_{5} / \mathrm{ha}$ ) from TSP $46 \%$ were implemented in the subplots. Each main plot was consisted of three subplots with four rows $(0.40 \mathrm{~m}$ between rows and $0.20 \mathrm{~m}$ between plants); thus, the plant population was 142,857 plant/ha. Planting date was on $12^{\text {th }}$ December of 2017 . The cultural operations and weed control were accomplished according to normal field practices. Half of recommended dose of fertilization were added to the whole experiment which were $50 \mathrm{Kg}$ Nitrogen/ha as urea and divided into two equal doses and were applied at the seeding time and after 20 days from germination.

The LSD test was done to find the significant differences between treatment means at $5 \%$ and $1 \%$ probability levels. Mature plants were harvested on $5^{\text {th }} \mathrm{July}$, of 2018 for estimating seed yield, yield components and growth rate.

The studied characters were:

- $50 \%$ flowering.

- Dry matter/plant (g/plant): the mean weight of five plant sample were dried in oven for $48 \mathrm{~h}$ in $65^{\circ} \mathrm{C}$ then weighted and recorded. 
- Plant height $(\mathrm{cm})$ : the mean height of the plant from ground level to the tip of five plants was recorded.

- No. of leaves/plant: the mean number of leaves per plant of the five plants was recorded.

- No. of seeds/plant: the mean number of seeds per plant of five plants was counted and recorded.

- 100 seed weight (g): 100 seeds were weighted and recorded and repeated three times.

- Oil \%: 2 gm of the harvested seed of each treatment was powdered by electric blender. Digital soxhlet instrument used for oil distillation, with n-hexane solvent (Ferreira-Dias et al., 2000), the oil content calculated as follows:

$$
\text { Oil percent }=\{(\mathrm{W} 2-\mathrm{W} 1) \times 100\} / \mathrm{S}
$$

$\mathrm{W} 1=$ weight of empty flask (g), W2 = weight of flask and extracted oil (g), $\mathrm{S}=$ weight of sample.

- Protein (\%): quantification of total protein by Bradford assay method (He, 2011).

- Ash content (\%): seed ash content was estimated by muffle furnace on the $550{ }^{\circ} \mathrm{C}$ according to the following equation:

$$
\text { Ash } \%=\text { Total ash } / \text { weight of the sample } \times 100
$$

- Biological yield ( $\mathrm{Kg} / \mathrm{ha})$ : the mean of weight of the five plant samples without the roots was recorded in each plot (g/plant) and converted to $\mathrm{Kg} / \mathrm{ha}$.

- Seed yield $(\mathrm{Kg} / \mathrm{ha})$ : the mean of seeds weight of the five plant samples was recorded in each plot (g/plant) and converted to $\mathrm{Kg} / \mathrm{ha}$.

\section{Correlation analysis}

The correlation coefficient was conducted to determine the degree of association of characters with seed yield and also among all the criteria studied. Phenotypic correlations were computed between the characters in the growing season using the formula given by Singh and Chaudhary (1985).

\section{Path coefficient analysis}

The path coefficient analysis was carried out as suggested by Dewey and Lu (1959). Seedyield was kept as resultant variable and other characters as causal through (Analysis of Moment Structures) AMOS Ver. 18 Software.

\section{Results and discussion}

Data in Table 3 confirm that the differences among varieties were highly significant for the studied criteria plant height, number of leaves per plant, dry matter weight oil \% and seed yield, while it was significant for the characters 100 -seed weight, Protein $\%$ and biological yield. More leave number, and oil percentage was obtained by Zaafarani, as compared to Aidn and; Al-shamia with values of 616.22 and 32.58 respectively, followed by Aidn which was recorded value of $133.88 \mathrm{~cm}$ plant high, values of 
102.25 g total plant dry mater accumulate (leave, stem, and flower dry weight) and values of $3.76 \mathrm{~g} \mathrm{100-seed} \mathrm{weight.} \mathrm{While,} \mathrm{Al-shamia} \mathrm{was} \mathrm{significant} \mathrm{in} \mathrm{producing}$ biological yield with value of $15398.22 \mathrm{Kg} / \mathrm{ha}$ and with value of $1914.06 \mathrm{Kg} / \mathrm{ha}$ for seed yield. This variation between the studied varieties was related to genetic variation and variation in their responses to the use of different levels of phosphorus fertilizer, as previously reported by Banna (2011) and Ryan et al. (2009).

Table 1. Average air temperature and rainfall during the growing seasons of 2017-2018 at Bakrajo location

\begin{tabular}{c|c|c|c}
\hline \multirow{2}{*}{ Months } & \multicolumn{2}{|c|}{ Average air temperature $\left(^{\circ} \mathbf{C}\right)$} & \multirow{2}{*}{ Rainfall (mm) } \\
\cline { 2 - 3 } & Max. & Min. & 10.0 \\
October & 33.1 & 10.4 & 114.6 \\
November & 23.9 & 7.6 & 22.2 \\
December & 17.8 & -2.5 & 72.4 \\
January & 15.6 & 1.4 & 323.0 \\
February & 20.9 & -2.3 & 44.6 \\
March & 24.4 & 1.0 & 98.6 \\
April & 31.6 & 2.2 & 70.4 \\
May & 38.1 & 13.0 & 755.8 \\
\hline Total & & & \\
\hline
\end{tabular}

Table 2. Physical and chemical properties of the studied soil

\begin{tabular}{c|c}
\hline Soil properties & Values \\
\hline Texture class & Clay \\
Sand (g kg-1) & 41.0 \\
Silt (g kg-1) & 430.50 \\
Clay (g kg-1) & 528.50 \\
EC (dS m-1) & 0.61 \\
pH & 7.32 \\
OM (g kg-1) & 21.60 \\
CaCO3 (g kg-1) & 107.0 \\
Total N (mg kg-1) & 1.07 \\
K + (mmoles l-1) & 0.32 \\
Na $+($ mmoles l-1) & 0.41 \\
Ca + (mmoles l-1) & 1.49 \\
Cl- (mmoles l-1) & 0.57 \\
\hline
\end{tabular}

Table 3. Means of variety on the studied characters

\begin{tabular}{|c|c|c|c|c|c|c|c|c|c|c|}
\hline Varieties & $\begin{array}{l}\text { Plant height } \\
\text { (cm) }\end{array}$ & \begin{tabular}{|c|} 
No. of \\
leaves/plan \\
$t$
\end{tabular} & $\begin{array}{c}\text { No. of } \\
\text { seeds/plant }\end{array}$ & $\begin{array}{c}\text { Dry } \\
\text { matter } \\
\text { (g/plant) }\end{array}$ & $\begin{array}{c}100 \text { Seed } \\
\text { weight }(g)\end{array}$ & $\begin{array}{c}\text { Oil } \\
\%\end{array}$ & $\begin{array}{c}\text { Protein } \\
\%\end{array}$ & $\begin{array}{c}\text { Ashe } \\
\%\end{array}$ & $\begin{array}{c}\text { Biological } \\
\text { yield } \\
(\mathrm{Kg} / \mathrm{ha})\end{array}$ & $\begin{array}{c}\text { Seed } \\
\text { yield } \\
(\mathbf{K g} / \mathbf{h a})\end{array}$ \\
\hline V1 & $130.11 \mathrm{a}$ & $616.22 \mathrm{a}$ & 505.56 & $91.92 \mathrm{~b}$ & 3.31 & $32.58 \mathrm{a}$ & 9.033 & 0.026 & 13662.88 & $1545.35 b$ \\
\hline $\mathrm{V} 2$ & $133.88 \mathrm{a}$ & $516.00 \mathrm{~b}$ & 461.00 & $102.25 \mathrm{a}$ & 3.76 & $29.62 \mathrm{~b}$ & 11.294 & 0.025 & 14508.77 & $1655.72 b$ \\
\hline V3 & $100.00 \mathrm{~b}$ & $554.89 \mathrm{~b}$ & 520.44 & $84.95 \mathrm{~b}$ & 3.68 & $28.10 \mathrm{c}$ & 9.243 & 0.026 & 15398.22 & $1914.06 \mathrm{a}$ \\
\hline $\operatorname{LSD}(\mathrm{P} \leq 0.05)$ & 9.72 & 59.99 & N.S & 7.91 & 0.34 & 0.90 & 1.595 & N.S & 1279.24 & 193.43 \\
\hline $\operatorname{LSD}(\mathrm{P}<0.01)$ & 13.39 & 82.65 & N.S & 10.90 & N.S & 1.24 & N.S & N.S & N.S & 266.51 \\
\hline
\end{tabular}

N.S: not significant 
The effect of phosphorus fertilizer application was found to be highly significant for all characters except of plant height and Ashe\% (Table 4). The best values of 658.22 , $561.78,101.971 \mathrm{~g}, 3.897 \mathrm{~g}, 31.59 \%, 12.99,16728.77 \mathrm{Kg} / \mathrm{ha}$ and $1972.433 / \mathrm{ha}$ for the number of leaves per plant, number of seeds per plant, dry matter weight, 100 seed weight, oil percentage, protein percentage, biological yield and seed yield respectively, were obtained by plants grown under $100 \mathrm{Kg}$ P/ha except protein percentage was obtained by plants grown under $0 \mathrm{Kg} \mathrm{P} / \mathrm{ha}$. While the lowest values of 473.333, 422.67, $81.906 \mathrm{~g}, 3.177 \mathrm{~g}, 28.69 \%, 7.94 \%, 11118.88 \mathrm{Kg} / \mathrm{ha}$ and $1470.06 \mathrm{Kg} / \mathrm{ha}$ for the number of leaves per plant, number of seeds per plant, dry matter weight, 100 seed weight, oil percentage, protein percentage, biological yield and seed yield respectively, were obtained by plants grown under control, except protein percentage was obtained by the plants grown under $100 \mathrm{Kg} \mathrm{P} / \mathrm{ha}$. Because Phosphorus plays a major role in several physiological processes like photo-synthesis, respiration, energy storage and transfer, cell division, cell enlargement and development of meristematic tissues (Mengal and Kirkby, 2000). In addition, $P$ is also an integral structural component of many biochemical, i.e. nucleic acids, which is the basic component of gene and chromosomes and asses to heredity (Blevins, 1999; Halvin et al., 1999). The P availability may affect yield formation by differential influence on individual yield components. However, little is known on this response in safflower as compared to sunflower (Kumar, 2000).

Data in Table 5 confirm that the interaction between varieties and phosphorus application levels was significant only for the character Biological Yield Regarding the characters of Biological yield the interaction between Aidnand $100 \mathrm{Kg} / \mathrm{ha}$ of phosphorus fertilizer recorded maximum Biological yield reached $18113.00 \mathrm{Kg} / \mathrm{h}$, while the minimum Biological yield was $9341.66 \mathrm{Kg} / \mathrm{h}$ recorded by the variety Aidnand the control treatment.

Data in Table 6 explain the correlation coefficients among the characters. Highly significant and positive correlation represented between seed yield and 100 seed weight similar finding was showed by Singh (2004), while significantly and positively correlated with no. of seeds/plant and biological yield this agree with Pavithra (2016). The character no. of leaves/plant showed highly significant and negative correlation with protein percent, while correlated highly significantly and positively with no. of seed/plant and correlated positively with the character oil percent. Highly significant and positive correlation observed between the characters no. of seed/plant and biological yield, whereas the characters no. of seed/plant was highly significantly and negatively correlated with protein percent. Data in the same table confirm the presence of significant and positive correlation between the character dry matter weight and biological yield. The estimation of correlation coefficient between the character 100 seed weight and biological yield were significant and positive. The character biological yield showed significant and negative correlation with protein percent.

Data in Table 7 represented the estimation of path coefficient analysis between characters. The character no. of Seeds/plant had maximum positive direct effect on seed yield/plant with 1.803 similar findings was also reported by Semahegn (2016), whereas the character oil\% showed maximum negative direct effect on seed yield/plant with 0.690 this result is correspondence with Jadhav (2016). All characters except the plant height and protein\% were exhibited maximum positive indirect effect via the character no. of seeds/plant on the seed yield/plant with $1.639,1.494,1.054,0.852$ and 0.781 , while maximum negative indirect effect was showed by the character protein $\%$ via no. of seeds/plant on the seed yield/plant with -1.678. 
Table 4. Effect of P fertilizer levels on the studied characters

\begin{tabular}{|c|c|c|c|c|c|c|c|c|c|c|}
\hline $\begin{array}{c}\text { Phosphorus } \\
\text { fertilizers levels } \\
(\mathrm{Kg} / \mathrm{h})\end{array}$ & $\begin{array}{c}\text { Plant height } \\
(\mathrm{cm})\end{array}$ & $\begin{array}{c}\text { No. of } \\
\text { leaves/plant }\end{array}$ & $\begin{array}{c}\text { No. of } \\
\text { seeds/plant }\end{array}$ & $\begin{array}{l}\text { Dry matter } \\
\text { (g/plant) }\end{array}$ & $\begin{array}{c}100 \text { Seed } \\
\text { weight }(\mathrm{g})\end{array}$ & Oil \% & Protein \% & Ashe \% & $\begin{array}{c}\text { Biological } \\
\text { yield (Kg/ha) }\end{array}$ & $\begin{array}{c}\text { Seed yield } \\
(\mathrm{Kg} / \mathrm{ha})\end{array}$ \\
\hline 0 & 120.78 & $473.33 \mathrm{c}$ & $422.67 \mathrm{~b}$ & $81.90 \mathrm{~b}$ & $3.17 \mathrm{~b}$ & $28.69 \mathrm{c}$ & $12.99 \mathrm{a}$ & 0.026 & $11118.88 \mathrm{~b}$ & $1470.067 \mathrm{c}$ \\
\hline 50 & 121.33 & $555.56 \mathrm{~b}$ & $502.56 \mathrm{ab}$ & $95.25 \mathrm{a}$ & $3.69 \mathrm{a}$ & $30.01 \mathrm{~b}$ & $8.63 \mathrm{~b}$ & 0.026 & $15722.22 \mathrm{a}$ & $1672.647 \mathrm{~b}$ \\
\hline 100 & 121.89 & $658.22 \mathrm{a}$ & $561.78 \mathrm{a}$ & $101.97 \mathrm{a}$ & $3.89 \mathrm{a}$ & $31.59 \mathrm{a}$ & $7.94 \mathrm{~b}$ & 0.025 & $16728.77 \mathrm{a}$ & $1972.433 \mathrm{a}$ \\
\hline LSD $(\mathrm{P} \leq 0.05)$ & 0.00 & 59.99 & 80.32 & 7.91 & 0.34 & 0.90 & 1.59 & 0.000 & 1279.24 & 193.433 \\
\hline $\operatorname{LSD}(\mathrm{P}<0.01)$ & N.S & 82.65 & 110.65 & 10.90 & 0.46 & 1.24 & 2.19 & N.S & 1762.52 & 266.510 \\
\hline
\end{tabular}

N.S.: not significant

Table 5. The interaction effect of varieties and phosphorus fertilizer levels on studied characters

\begin{tabular}{|c|c|c|c|c|c|c|c|c|c|c|}
\hline $\begin{array}{c}\text { Varieties } \times \\
\text { phosphorus } \\
\text { fertilizer levels } \\
\mathrm{Kg} / \mathrm{ha}\end{array}$ & $\begin{array}{c}\text { Plant height } \\
(\mathrm{cm})\end{array}$ & $\begin{array}{c}\text { No. of } \\
\text { leaves/plant }\end{array}$ & $\begin{array}{c}\text { No. of } \\
\text { seeds/plant }\end{array}$ & $\begin{array}{c}\text { Dry matter } \\
\text { weight } \\
\text { (g/plant) }\end{array}$ & $\begin{array}{c}100 \text { seed } \\
\text { weight }(g)\end{array}$ & Oil \% & Protein \% & Ashe\% & $\begin{array}{c}\text { Biological yield } \\
\text { (Kg/ha) }\end{array}$ & $\begin{array}{c}\text { Seed yield } \\
\text { (Kg/ha) }\end{array}$ \\
\hline Zaafarani $\times 0$ & $127.33 \mathrm{a}$ & $529.33 \mathrm{a}$ & $429.67 \mathrm{a}$ & $82.80 \mathrm{a}$ & $2.93 \mathrm{a}$ & $30.84 \mathrm{a}$ & $12.91 \mathrm{a}$ & $0.025 \mathrm{a}$ & $11689.33 \mathrm{e}$ & $1313.76 \mathrm{a}$ \\
\hline Zaafarani $\times 50$ & $126.00 \mathrm{a}$ & $608.67 \mathrm{a}$ & $508.67 \mathrm{a}$ & $93.76 \mathrm{a}$ & $3.39 \mathrm{a}$ & $32.35 \mathrm{a}$ & $7.38 \mathrm{a}$ & $0.027 \mathrm{a}$ & $13914.00 \mathrm{~cd}$ & $1440.93 \mathrm{a}$ \\
\hline Zaafarani $\times 100$ & $137.00 \mathrm{a}$ & $710.67 \mathrm{a}$ & $578.33 \mathrm{a}$ & $99.22 \mathrm{a}$ & $3.63 \mathrm{a}$ & $34.55 \mathrm{a}$ & $6.80 \mathrm{a}$ & $0.025 \mathrm{a}$ & $15385.33 \mathrm{bc}$ & $1881.36 \mathrm{a}$ \\
\hline Aidn $\times 0$ & $133.00 \mathrm{a}$ & $425.67 \mathrm{a}$ & $382.00 \mathrm{a}$ & $84.40 \mathrm{a}$ & $3.57 \mathrm{a}$ & $28.07 \mathrm{a}$ & $15.05 \mathrm{a}$ & $0.026 \mathrm{a}$ & $9341.66 \mathrm{f}$ & $1542.66 \mathrm{a}$ \\
\hline Aidn $\times 50$ & $132.66 \mathrm{a}$ & $509.00 \mathrm{a}$ & $466.33 \mathrm{a}$ & $104.91 \mathrm{a}$ & $3.82 \mathrm{a}$ & $29.14 \mathrm{a}$ & $9.94 \mathrm{a}$ & $0.024 \mathrm{a}$ & $16071.66 \mathrm{abc}$ & $1600.40 \mathrm{a}$ \\
\hline Aidn $\times 100$ & $136.00 \mathrm{a}$ & $613.33 \mathrm{a}$ & $534.67 \mathrm{a}$ & $117.43 \mathrm{a}$ & $3.90 \mathrm{a}$ & $31.10 \mathrm{a}$ & $8.89 \mathrm{a}$ & $0.025 \mathrm{a}$ & $18113.00 \mathrm{a}$ & $1824.10 \mathrm{a}$ \\
\hline Al-shamia $\times 0$ & $102.00 \mathrm{a}$ & $465.00 \mathrm{a}$ & $456.33 \mathrm{a}$ & $78.51 \mathrm{a}$ & $3.02 \mathrm{a}$ & $27.09 \mathrm{a}$ & $11.03 \mathrm{a}$ & $0.027 \mathrm{a}$ & $12325.66 \mathrm{de}$ & $1553.76 \mathrm{a}$ \\
\hline Al-shamia $\times 50$ & $105.33 \mathrm{a}$ & $549.00 \mathrm{a}$ & $532.67 \mathrm{a}$ & $87.09 \mathrm{a}$ & $3.87 \mathrm{a}$ & $28.14 \mathrm{a}$ & $8.56 \mathrm{a}$ & $0.026 \mathrm{a}$ & $17181.00 \mathrm{ab}$ & $1976.60 \mathrm{a}$ \\
\hline Al-shamia $\times 100$ & $92.66 \mathrm{a}$ & $650.67 \mathrm{a}$ & $572.33 \mathrm{a}$ & $89.26 \mathrm{a}$ & $4.15 \mathrm{a}$ & $29.61 \mathrm{a}$ & $8.13 \mathrm{a}$ & $0.026 \mathrm{a}$ & $16688.00 \mathrm{ab}$ & $2211.83 \mathrm{a}$ \\
\hline L.S.D $(\mathrm{P} \leq 0.05)$ & N.S & N.S & N.S & N.S & N.S & N.S & N.S & N.S & 2215.71 & N.S \\
\hline L.S.D $(P \leq 0.01)$ & N.S & N.S & N.S & N.S & N.S & N.S & N.S & N.S & N.S & N.S \\
\hline
\end{tabular}

N.S: not significant 
Table 6. Correlation coefficients among the characters

\begin{tabular}{|c|c|c|c|c|c|c|c|c|c|c|}
\hline & $\begin{array}{c}\text { Seed yield } \\
(\mathrm{Kg} / \mathrm{ha})\end{array}$ & \begin{tabular}{|c|}
$\begin{array}{c}\text { Plant height } \\
(\mathrm{cm})\end{array}$ \\
\end{tabular} & $\begin{array}{c}\text { No. of } \\
\text { leaves/plant }\end{array}$ & \begin{tabular}{|c|} 
No. of \\
seeds/plant
\end{tabular} & $\begin{array}{c}100 \text { seed } \\
\text { weight }(\mathrm{g})\end{array}$ & $\begin{array}{c}\text { Dry matter } \\
\text { (g/plant) }\end{array}$ & $\begin{array}{c}\text { Biological yield } \\
\text { (Kg/ha) }\end{array}$ & Oil \% & Protein \% & Ashe \% \\
\hline Seed yield $(\mathrm{Kg} / \mathrm{ha})$ & 1 & & & & & & & & & \\
\hline Plant height $(\mathrm{cm})$ & $-0.472^{\mathrm{n} . \mathrm{s}}$ & 1 & & & & & & & & \\
\hline No. of leaves/plant & $0.555^{\mathrm{n} . \mathrm{s}}$ & $0.037^{\mathrm{n} . \mathrm{s}}$ & 1 & & & & & & & \\
\hline No. of seeds/plant & $0.772^{*}$ & $-0.242^{\text {n.s }}$ & $0.909^{* *}$ & 1 & & & & & & \\
\hline 100 seed weight $(\mathrm{g})$ & $0.829^{* *}$ & $-0.125^{\mathrm{n} . \mathrm{s}}$ & $0.420^{\mathrm{n} . \mathrm{s}}$ & $0.585^{\mathrm{n} . \mathrm{s}}$ & 1 & & & & & \\
\hline Dry matter (g/plant) & $0.235^{\mathrm{n} . \mathrm{s}}$ & $0.555^{\mathrm{n} . \mathrm{s}}$ & $0.471^{\mathrm{n} . \mathrm{s}}$ & $0.433^{\mathrm{n} . \mathrm{s}}$ & $0.540^{\mathrm{n} . \mathrm{s}}$ & 1 & & & & \\
\hline Biological yield (Kg/ha) & $0.700^{*}$ & $-0.151^{\mathrm{n} . \mathrm{s}}$ & $0.644^{\text {n.s }}$ & $0.828^{* *}$ & $0.713^{*}$ & $0.671^{*}$ & 1 & & & \\
\hline Oil \% & $-0.036^{\mathrm{n} . \mathrm{s}}$ & $0.599^{\text {n.s }}$ & $0.765^{*}$ & $0.472^{\text {n.s }}$ & $0.011^{\mathrm{n} . \mathrm{s}}$ & $0.500^{\mathrm{n} . \mathrm{s}}$ & $0.227^{\text {n.s }}$ & 1 & & \\
\hline Protein $\%$ & $-0.555^{\mathrm{n} . \mathrm{s}}$ & $0.148^{\text {n.s }}$ & $-0.849^{* *}$ & $-0.931^{* *}$ & $-0.453^{\mathrm{n} . \mathrm{s}}$ & $-0.458^{\text {n.s }}$ & $-0.789^{*}$ & $-0.534^{\mathrm{n} . \mathrm{s}}$ & 1 & \\
\hline Ashe $\%$ & $-0.048^{\mathrm{n} . \mathrm{s}}$ & $-0.551^{\mathrm{n} . \mathrm{s}}$ & $-0.151^{\mathrm{n} . \mathrm{s}}$ & $-0.044^{\text {n.s }}$ & $-0.284^{\mathrm{n} . \mathrm{s}}$ & $-0.587^{\mathrm{n} . \mathrm{s}}$ & $-0.323^{\text {n.s }}$ & $-0.316^{\text {n.s }}$ & $-0.024^{\text {n.s }}$ & 1 \\
\hline
\end{tabular}

N.S: Not significant; *: Significant; **: Highly significant

Table 7. Path coefficient analysis confirming direct (diagonal values) and indirect effects among the characters

\begin{tabular}{|c|c|c|c|c|c|c|c|c|c|}
\hline & $\begin{array}{c}\text { Plant height } \\
(\mathrm{cm})\end{array}$ & $\begin{array}{c}\text { No. of } \\
\text { seeds/plant }\end{array}$ & $\begin{array}{c}100 \text { seed } \\
\text { weight }(g)\end{array}$ & $\begin{array}{c}\text { Dry matter } \\
\text { (g/plant) }\end{array}$ & $\begin{array}{c}\text { Biological } \\
\text { yield (Kg/ha) }\end{array}$ & Oil \% & Protein \% & Ashe \% & $\begin{array}{c}\text { Correlation } \\
\text { seed yield } \\
\text { (Kg/ha) }\end{array}$ \\
\hline Plant height $(\mathrm{cm})$ & 0.266 & -0.437 & -0.049 & -0.057 & 0.074 & -0.413 & 0.067 & 0.077 & -0.472 \\
\hline No. of leaves/plant & 0.010 & 1.639 & 0.163 & -0.048 & -0.318 & -0.528 & -0.384 & 0.021 & 0.555 \\
\hline No. of seeds/plant & -0.064 & 1.803 & 0.227 & -0.044 & -0.409 & -0.326 & -0.421 & 0.006 & 0.772 \\
\hline 100 Seed weight $(\mathrm{g})$ & -0.033 & 1.054 & 0.389 & -0.055 & -0.352 & -0.008 & -0.205 & 0.040 & 0.829 \\
\hline Dry matter t (g/plant) & 0.147 & 0.781 & 0.210 & -0.102 & -0.331 & -0.345 & -0.207 & 0.082 & 0.235 \\
\hline Biological yield ( $\mathrm{Kg} / \mathrm{ha})$ & -0.040 & 1.494 & 0.277 & -0.069 & -0.494 & -0.157 & -0.357 & 0.045 & 0.700 \\
\hline Oil \% & 0.159 & 0.852 & 0.004 & -0.051 & -0.112 & -0.690 & -0.242 & 0.044 & -0.036 \\
\hline Protein $\%$ & 0.039 & -1.678 & -0.176 & 0.047 & 0.389 & 0.369 & 0.452 & 0.003 & -0.555 \\
\hline Ashe \% & -0.146 & -0.079 & -0.110 & 0.060 & 0.159 & 0.218 & -0.011 & -0.139 & -0.048 \\
\hline
\end{tabular}




\section{Conclusions and recommendation}

From the results obtained in this study, it can be concluded that the variety of Zaafarani with non-phosphorus fertilizer application to cultivate for produce oil yield. However, the variety of Al-shamia with the level of $100 \mathrm{Kg}_{2} \mathrm{O}_{5} /$ ha for produce economic seed yield under the rain fed condition of Sulaimani province and both traits observed to be the most important trait for seed yield improvement in safflower, so we recommended cultivation of these varieties in our region under the application of 100 $\mathrm{Kg} \mathrm{P}_{2} \mathrm{O}_{5} /$ ha to reach maximum yield.

\section{REFERENCES}

[1] Arslan, B., Altuner, F., Tuncturk, M. (2003): An investigation on yield and yield components of some safflower varieties which grown in Van. - 5th Field Crops Congress of Turkey 1: 468-472.

[2] Banna, M. N. (2011): Evaluation of 16 barley genotypes under calcareous soil conditions in Egypt. - J. Agric. Sci. 3(1): 105-121.

[3] Belgin, C., Bilal, G., Mustafa, K. (2007): Oil content and fatty acid composition of some safflower (Cartham ustinctorius L.) varieties sown in spring and winter. - Inter. J. Nat. and Eng. Sci. 1(3): 11-15.

[4] Blevins, D. G. (1999): Why plants need phosphorus. - Better Crops 83: 29-30.

[5] Dambroth, M., El-Bassam, N. (1990): Genotypic Variation in Plant Productivity and Consequences for Breeding of Low-Input Cultivars. - In: El-Bassam, N., Dambroth, M. C., Loughman, B. C. (eds.) International Symposium on Genetic Aspects of Plant Mineral Nutrition. Kluwer Academic Publishers, Dordrecht.

[6] Dewey, D. R., Lu, K. H. (1959): A correlation and path-coefficient analysis of components of crested wheatgrass grain production. - Agronomy Journal 51: 515-518.

[7] Dordas, C., Sioulas, C. (2008): Safflower yield, chlorophyll content, photosynthesis, and water use efficiency response to nitrogen fertilization under rainfed conditions. - Indian Crop Production 27: 75-85.

[8] Guest, E. (1966) Flora of Iraq. Vol. 1. - Ministry of Agricultural, Baghdad.

[9] Halvin, J. L., Beaton, J. D., Tisdale, S. L., Nelson, W. L. (1999): Soil Fertility and Fertilizers, an Introduction to Nutrient Management. 6th Ed. - Pearson Education, Singapore, pp.154-196.

[10] He, F. (2011) Bradford protein assay. - Bio 101: e45. DOI: 10.21769/BioProtoc.45.

[11] Jadhav, S. A., Dhuppe, M. V., Salunke, P. M. (2016): Correlation coefficient and path analysis in safflower (Carthamus tincorius, L.). - International Journal of Current Microbiology and Applied Sciences 2016(Special Issue). https: www.ijcmas.com.

[12] Kumar, H. (2000): Development potential of safflower in comparison to sunflower. Sesame and Safflower Newsletter 15: 86-89.

[13] Mengal, K., Kirkby, E. A. (2000): Principles of Plant Nutrition. $5^{\text {th }}$ Ed. - Int'l. Potash Instt., Switzerland.

[14] Omidi-Tabrizi, A. H., Ahmadi, M. R., Shahsavarii, M. R., Karimi, S. (2000): Evaluation of oil and seed yield stability on some of safflower winter variety and lines. - Seed and Plant Improvement Journal 16(2): 130-145 (in Persian with English abstract).

[15] Pavithra, K. P., Rajesh, Patil, S., Yallappa, H., Nishanth, G. K. (2016): Correlation and path analysis studies in safflower (Carthamus tinctorius L.) germplasm. - Research Journal of Agricultural Sciences 7(2): 428-432. https: www.rjas.org. 
[16] Rastgou, B., Ebadi, A., Vafaie, A., Moghadam, S. H. (2013): The effects of nitrogen fertilizer on nutrient uptake, physiological traits and yield components of safflower (Carthamus tinctorius L.). - Int. J. Agron. Plant Prod 4(3): 355-364.

[17] Rodriguez, D., Andrade, F. H., Goudriaan, J. (1999): Effects of phosphorus nutrition on tiller emergence in wheat. - Plant and Soil 209: 283-295.

[18] Roy, R. N., Finck, A., Blair, G. J., Tandon, H. L. S. (2006): Plant Nutrition for Food Security, a Guide for Integrated Nutrient Management. - FAO Fertilizer and Plant Nutrition Bulletin 16. FAO, Rome.

[19] Ryan, J., Abdel-Monem, M., Amir, A. (2009): Nitrogen fertilizer response of some barley varieties in semi-arid in Morocco. - J. Agric. Sci. Technol. 11: 227-236.

[20] Semahegn, Y., Tesfaye, M. (2016): Characters Associations and Path Analysis in Safflower (Carthamus tinctorious) Accessions. - Holetta Research Center, Ethiopian Institute of Agricultural Research, Molecular Plant Breeding, Vol. 7, No. 31.

[21] Sing, R. K., Chaudhary, B. D. (1985): Biometrical Methods in Quantitative Genetic Analysis. Revised Edition. - Kalyani Publishers, Ludhiana.

[22] Sultenfuss, J. H., Doyle, W. J. (1999): Functions of Phosphorus in Plants. - Better Crops 83 (1): $6-7$.

[23] Vrijendra, S., Deshpande, M. B., Choudhari, S. V., Nimbkar, N. (2004): Correlation and Path Coefficient Analysis in Safflower (Carthamus tinctorius L.). - Nimbkar Agricultural Research Institute (NARI), Maharashtra.

[24] Weiss, E. A. (2000): Oilseed Crops. 2nd Ed. - Blackwell Science, Oxford. 


\section{APPENDIX}

Table A1. Mean squares of variance analysis for seed yield and its components of studied characters

\begin{tabular}{|c|c|c|c|c|c|c|c|c|c|c|c|}
\hline S.O.V & d.f & $\begin{array}{l}\text { Plant high } \\
\quad(\mathbf{c m})\end{array}$ & $\begin{array}{c}\text { No. of } \\
\text { leaves/plant }\end{array}$ & $\begin{array}{c}\text { No. of } \\
\text { seeds/plant }\end{array}$ & \begin{tabular}{|c|} 
Dry \\
weight/plant (g)
\end{tabular} & $\begin{array}{c}100 \text { seed } \\
\text { weight }(\mathrm{gm})\end{array}$ & Oil \% & Protein \% & Ashe\% & $\begin{array}{c}\text { Biological yield } \\
\mathrm{Kg} / \mathrm{ha}\end{array}$ & $\begin{array}{c}\text { Seed } \\
\text { yield/ka/ha }\end{array}$ \\
\hline Blocks & $\mathrm{r}-1=2$ & 116.33 & 6188.25 & 6132.00 & 1.76 & 0.11 & 3.55 & 3.187 & -0.006 & 19608914.37 & 44884.00 \\
\hline A (varieties) & $a-1=2$ & $3104.11^{* *}$ & $22977.92 * *$ & $8610.77^{\text {N.S }}$ & $681.30^{* *}$ & $0.51 *$ & $46.69 * *$ & $14.046^{*}$ & $0.000^{\mathrm{N} . \mathrm{S}}$ & $6777031.81 *$ & $320265.44 * *$ \\
\hline $\begin{array}{l}\text { B (phosphorus fertilizer } \\
\text { levels }(\mathrm{Kg} / \mathrm{ha})\end{array}$ & $b-1=2$ & $2.77^{\mathrm{N} . \mathrm{S}}$ & $77227.25 * *$ & $43862.11 * *$ & $938.96 * *$ & $1.24 * *$ & $19.02 * *$ & $67.688^{* * *}$ & $0.000^{\mathrm{N} . \mathrm{S}}$ & $80512027.81 * *$ & $573808.00 * *$ \\
\hline $\begin{array}{l}\text { Varieties } \times \text { phosphorus } \\
\text { fertilizer levels }(\mathrm{Kg} / \mathrm{ha})\end{array}$ & $(a-1)(b-1)=4$ & $122.38^{\mathrm{N} . \mathrm{S}}$ & $9.48^{\mathrm{N.S}}$ & $354.22^{\mathrm{N} . S}$ & $100.86^{\mathrm{N} . \mathrm{S}}$ & $0.13^{\mathrm{N} . \mathrm{S}}$ & $0.55^{\text {N.S }}$ & $3.173^{\text {N.S }}$ & $0.000^{\mathrm{N} . \mathrm{S}}$ & $7248454.25^{\text {N.S }}$ & $44976.44^{\text {N.S }}$ \\
\hline Error (b) & $\mathrm{a}(\mathrm{b}-1)(\mathrm{r}-1)=16$ & 94.62 & 3604.09 & 6460.08 & 62.70 & 0.11 & 0.81 & 2.548 & 0.001 & 1638641.78 & 37320.00 \\
\hline Total & abr- $1=26$ & 116.33 & 6188.25 & 6132.00 & 1.76 & 0.11 & 3.55 & 3.187 & -0.006 & 19608914.37 & 44884.00 \\
\hline
\end{tabular}

N.S: Not significant; *: Significant; **: Highly significant

Table A2. Correlation coefficients among the characters

\begin{tabular}{|c|c|c|c|c|c|c|c|c|c|c|}
\hline & $\begin{array}{c}\begin{array}{c}\text { Seed yield } \\
(\mathrm{Kg} / \mathrm{ha})\end{array} \\
\end{array}$ & $\begin{array}{c}\text { Plant height } \\
(\mathbf{c m})\end{array}$ & $\begin{array}{c}\begin{array}{c}\text { No. of } \\
\text { leaves/plant }\end{array} \\
\end{array}$ & $\begin{array}{c}\begin{array}{c}\text { No. of } \\
\text { seeds/plant }\end{array} \\
\end{array}$ & $\begin{array}{c}100 \text { seed } \\
\text { weight }(\mathrm{g})\end{array}$ & $\begin{array}{c}\text { Dry matter } \\
\text { (g/plant) }\end{array}$ & $\begin{array}{c}\text { Biological yield } \\
(\mathbf{K g} / \mathbf{h a})\end{array}$ & $\begin{array}{l}\text { Oil } \\
\%\end{array}$ & Protein \% & $\begin{array}{c}\text { Ashe } \\
\%\end{array}$ \\
\hline Seed yield $(\mathrm{Kg} / \mathrm{ha})$ & 1 & & & & & & & & & \\
\hline Plant height $(\mathrm{cm})$ & -1.413 & 1 & & & & & & & & \\
\hline No. of leaves/plant & 1.767 & 0.098 & 1 & & & & & & & \\
\hline No. of seeds/plant & 3.213 & -0.661 & 5.767 & 1 & & & & & & \\
\hline 100 seed weight $(\mathrm{g})$ & 3.927 & -0.334 & 1.226 & 1.907 & 1 & & & & & \\
\hline Dry matter weight (g/plant) & 0.639 & 1.766 & 1.411 & 1.272 & 1.699 & 1 & & & & \\
\hline Biological yield (Kg/ha) & 2.592 & -0.404 & 2.228 & 3.911 & 2.691 & 2.392 & 1 & & & \\
\hline Oil \% & -0.094 & 1.979 & 3.140 & 1.418 & 0.029 & 1.530 & 0.617 & 1 & & \\
\hline Protein $\%$ & -1.763 & 0.397 & -4.247 & -6.732 & -1.345 & -1.362 & -3.394 & -1.671 & 1 & \\
\hline Ashe $\%$ & -0.127 & -1.746 & -0.405 & -0.116 & -0.783 & -1.919 & -0.902 & -0.882 & -0.063 & 1 \\
\hline $\mathrm{t}(\mathrm{P} \leq 0.05)$ & 2.365 & & & & & & & & & \\
\hline $\mathrm{t}(\mathrm{P} \leq 0.01)$ & 3.499 & & & & & & & & & \\
\hline
\end{tabular}

